\title{
EDITORIAL 2021.1
}

O Curso de Mestrado em Direito da Universidade Metodista de Piracicaba apresenta mais uma edição de Cadernos de Direito tendo por tema "Os Direitos Fundamentais Coletivos e Difusos".

Partindo-se do tema central da Revista, tem-se o direito à vida e à saúde, como os maiores bens a serem garantidos, vez que sem eles o ser humano não terá chance de fruir de nenhum outro.

Sob esse aspecto, não podíamos deixar de registrar e lamentar as mais de 600 mil mortes, contabilizadas nessa data, ocasionadas em razão da pandemia, provocada pela Covid-19, que assola o país. Mundialmente, em outubro de 2021, foram registrados mais de 4,5 milhões de falecimentos.

Em um tempo tão obscuro como este, que em número de óbitos pode ser equiparado a uma guerra mundial, a humanidade precisa esquecer suas diferenças, ser solidária, ter empatia, repensar a forma de viver, amar o próximo e apoiar a pesquisa e a ciência, para então termos a esperança de superarmos essa tragédia e alcançar um mundo melhor.

Nesse sentido, a produção de conhecimento do Programa de Mestrado em Direito da Universidade Metodista de Piracicaba (UNIMEP) tem sido guiada pela área de concentração de pesquisa da instituição, que é o estudo e a produção no campo dos Direitos Fundamentais Coletivos e Difusos.

Os textos aqui apresentados abordam essa linha de trabalhar com fatos e como o Direito é a eles aplicado, sempre com o pano de fundo da proteção dos direitos fundamentais coletivos e difusos. Sob esse viés, os artigos científicos publicados abarcam os temas:

Uma alternativa de arrecadação emergencial: os empréstimos compulsórios, de William Eufrasio Nunes Pereira e André de Souza Dantas Elali. Os autores, a partir da consideração da dificuldade do aumento da carga tributária, abordam a defesa do empréstimo compulsório como uma alternativa rápida e viável em um momento de crise econômica, acentuada pela crise política e radicalizada pela crise na saúde.

Direito humano à vida: a objeção médica e a interrupção de gravidez, de Regiane Nistler e Marco Augusto Ghisi Machado. Os autores discutem o direito à vida em relação à objeção médica e à possibilidade de a mulher interromper a própria gravidez, visto sua relevância jurídico-penal e o temor de consequências legais e sociais que recaem sobre o profissional de saúde objetor.

A proteção jurídica das pesquisadoras no Brasil: o desafio da mulher na ciência, de Julia Stefanello Pires, Letícia Scheidt Gregianin e Mariana Lira de Freitas. As autoras analisam a participação feminina na vida acadêmica, abordando no debate os obstáculos 
causados pela desigualdade de gênero que as impedem ou, no mínimo, dificultam uma ascensão na carreira de pesquisa.

Biodiversidade marinha brasileira: a importância da conservação marinha e o cumprimento dos compromissos internacionais pelo Brasil, de Aleph Hassan Costa Amin, Milena Furtado Farias e Dielle Alana Albuquerque Carneiro. Os autores abordam a questão da conservação da biodiversidade marinha brasileira, com o objetivo de analisar o grau de eficiência e importância dados pelo Governo Brasileiro às metas de Aichi para 2020, instituídas na $10^{\mathrm{a}}$ reunião das partes - COP 10 , referentes à biodiversidade marinha, por meio de documentos oficiais como o sexto relatório Nacional para a Convenção sobre Diversidade Biológica.

$O$ direito à privacidade e os novos desafios da era da informação no século XXI, de Andrei Fredes e Mariana Borges. Os autores analisam o assunto a partir da delimitação da tradição na qual se constrói o direito à privacidade como garantia fundamental, apresentam a sociedade atual globalizada e difusa como antítese e buscam a subsunção da tradição e da tecnologia em uma síntese capaz de responder os anseios sociais frente aos novos desafios propostos, especialmente o do perfilamento (profiling) massivo e de suas aplicações.

Os direitos de propriedade intelectual como estratégia de libertação do Japão da dependência econômica dos Estados Unidos no pós-guerra do século XIX, de Guilherme Aparecido da Silva Maia, Rosemary Matias e Ademir Kleber Morbeck de Oliveira. Os autores, analisam a consolidação do desenvolvimento econômico do Japão a partir da proteção da propriedade intelectual, bem como a sua estruturação e relevância como garantidor de uma liderança econômica mundial.

A Portaria 1.129/2017 e o impacto na fiscalização do trabalho em condições análogas à de escravo no Brasil contemporâneo, de Carine Azevedo Saraiva. A autora debruça-se sobre a atual situação de trabalhadores brasileiros que estão diariamente expostos a condições de trabalho degradantes e vêm exercendo suas funções em ambientes de trabalho cujo cenário é de escravidão, de forma a entender como as autoridades têm realizado a fiscalização de tais locais de trabalho após a implantação da Portaria 1.129/2017, com vista a observar os impactos e os movimentos feitos a fim de erradicar o problema da exploração da mão de obra.

Da sobrecarga de trabalho ao desemprego: os impactos da pandemia sobre a mulher que trabalha. As autoras analisam a desigualdade de gênero no âmbito laboral, no qual a proteção às mulheres foi concentrada no estado gravídico, situação que acaba acarretando, sob a ótica dos empregadores, uma maior onerosidade, o que, muitas vezes, em um efeito oposto ao desejado, dificulta o acesso ao mercado de trabalho, levando as empresas a optarem por profissionais homens, além disso a pandemia causada pelo Coronavírus agravou ainda mais tal questão ante a sobrecarga da rotina de inúmeras mulheres, promovendo a junção das jornadas (laborativas, de cuidados de pessoas e afazeres domésticos) no âmbito privado, modificando a estrutura das relações de trabalho e tornando subjetivo o limite de horas trabalhadas, o pagamento de adicional noturno, o grau de cobrança por produtividade, entre outros, sendo esse o cerne do estudo.

A reforma trabalhista e a liquidez das relações de trabalho, de Leonardo Brandalise Machado. O autor, a partir da leitura das obras de Bauman, examina como a reforma trabalhista, aprovada no Brasil por meio da Lei Ordinária 13467/2017, atua como legi- 
timadora para que as relações de trabalho se tornem cada vez mais líquidas e legitimem uma nova forma de pensar das relações laborais, defendida pelo modelo de capitalismo neoliberal, na qual predomina a mentalidade de curto prazo e a falta de identidade do trabalhador com a empresa.

Regime de proteção de dados pessoais sensiveis e transparência pública: institutos em aparente conflito, de Vilson Pedro Nery. O autor analisou em que medida a transparência das ações públicas permite o controle social e o governo aberto, de modo que as informações gerais produzidas pela administração pública fiquem disponibilizadas, inclusive em dados abertos, para consulta pública na Internet, bem como identificar se há algum conflito aparente de normas e se o sistema capitalista usa as amarras burocráticas a seu favor.

A presente edição de Cadernos de Direito acredita que cada artigo aqui publicado possa contribuir, de forma singular e efetiva, para a construção de um debate acadêmico produtivo e crítico do Direito, bem como de um conhecer jurídico alicerçado e atual.

Profa. Dra. Vivian A. Gregori Torres 